\title{
New Collections of Range Plants from the Soviet Union
}

\author{
D.R. DEWEY AND A.P. PLUMMER
}

\section{Abstract}

Range revegetation in the temperate arid and semiarid regions of the United States has been accomplished to a considerable extent with species introduced from Asia, particularly the Soviet Union. Only a small part of the Asian range-forage germplasm has been collected and evaluated in the United States. A 45-day plantcollecting expedition was authorized during the summer of 1977 to five locations in the U.S.S.R.-Stavropol, Tselinograd, Alma Ata., Dzhambul, and Chimkent. About 1,100 seed collections were made of 250 species, most of which were grasses and legumes from arid or semiarid sites. Large collections were made of Agropyron cristatum, A. desertorum, A. intermedium, A. repens, Bromus inermis, Dactylis glomerata, Festuca sulcata, Medicago falcataromanica, $M$. sativa, and Trifolium ambiguum. All collections have been established at Logan, Utah. Preliminary observations indicate that certain collections may be useful for forage or conservation purposes on rangeland. All accessions have been entered into the National Plant Germplasm System, and seed will be available for research and evaluation purposes in 1979 or succeeding years.

The United States is a "have-not" nation with respect to native agriculturally important plant species. For example, the small grains (Triticum, Hordeum, Secale) come from Eurasia; rice (Oryza sativa) and soybeans (Glycine max) from the Far East; and tomatoes (Lycopersicon esculentum) and potatoes (Solanum tuberosum) from South America (Harlan 1976). Even corn (Zea mays) is not indigenous to the U.S. but had its origin in Central America. We are equally dependent on other parts of the world for our major forage crops - the alfalfas (Medicago), clovers (Trifolium), and grasses (Bromus, Dactylis, Agropyron, Festuca).

Much of the revegetation of temperate arid and semiarid western rangeland has been accomplished with introduced grasses-viz. crested wheatgrass (Agropyron cristatum, $A$. desertorum), intermediate wheatgrass ( $A$. intermedium, $A$. trichophorum), tall, wheatgrass ( $A$. elongatum), and Russian wildrye (Elymus junceus). On the upper foothills and higher mountain ranges, restoration depends heavily on other introduced grasses including smooth bromegrass (Bromus inermis), meadow foxtail (Alopecurus pratensis), orchardgrass (Dactylis glomerata), and tall oatgrass (Arrhenatherum elatius).

In recent years, more emphasis has been given to the use of native plants in range revegetation (Plummer et al. 1968), and considerable sentiment prevails that native plants should be used to the exclusion of exotics. Plant breeders and range scientists must be committed to the best plant materials regardless of their geographic origin. To do otherwise would unnecessarily hinder range improvement.

\footnotetext{
Authors are research geneticist, SEA-AR, U.S. Department of Agriculture, Utah State University, Logan, Utah 84322, and range scientist, Forest Service, U.S. Dep. Agr., Shrub Sciences Laboratory, Brigham Young University, Provo, Utah 84602. This report is approved as Journal Paper No. 2392, Utah Agricultural Experiment Station.

Manuscript received February 13, 1979.
}

Although millions of acres have been seeded to crested wheatgrass, most of these seedings can be traced back to no more than a dozen introductions (Dillman 1946). The genetic base of the intermediate wheatgrass and Russian wildrye grown in the U.S. is even narrower than that of crested wheatgrass. The recent increased awareness of the genetic hazards of seeding large acreages to a single species with a narrow genetic base has stimulated the search for additional sources of grasses, forbs, and shrubs to be used in mixed plantings on range. Recognizing the need to expand the germplasm base of forage plants commonly seeded on arid rangeland, the U.S. Department of Agriculture sponsored a plant-collecting expedition to the Soviet Union. After lengthy negotiations a 45-day expedition (Fig. 1) July 18-August 31, 1977, was authorized for two plant collectors (D.R. Dewey and A.P., Plummer) and an interpreter (L.E. Law).

\section{Collecting Procedures}

The Soviets provided land transportation and local

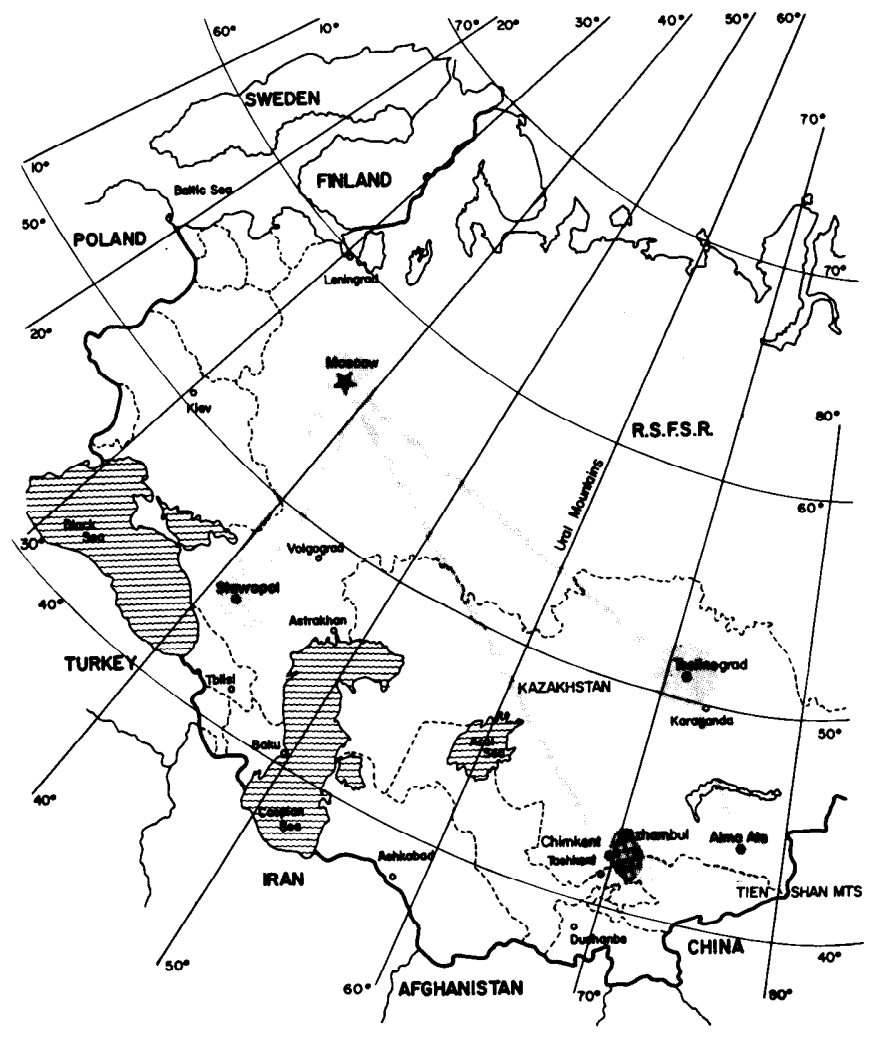

Fig. 1. Route of plant-collecting team in the Soviet Union in the summer of 1977. 


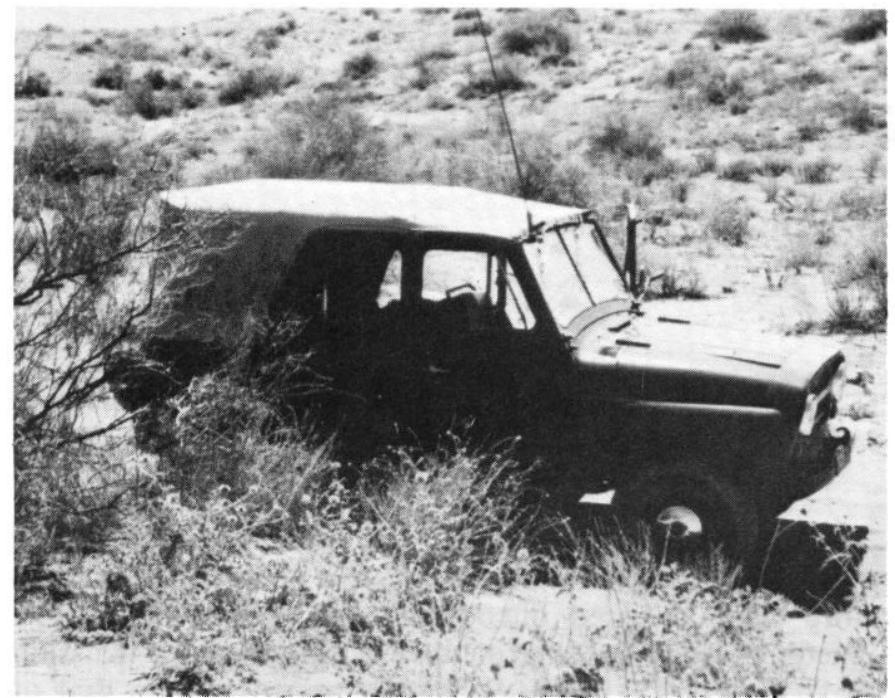

Fig. Soviet "jeep" used to traverse rough terrain in the Moyun-Kum Desert Dzhambul.

escorts. Land transportation usually consisted of durable 4wheel drive vehicles, which permitted access to rough offroad terrain (Fig. 2).

Most collections were made as seed. The size of individual collections ranged from less than 100 seeds to several thousand, depending on the size of the seed, its availability, and the size and nature of the population being sampled. Vegetative cuttings or seedlings were taken from some of the woody species that did not have seed at the time of our visit. However, all of the vegetative material was subsequently lost in a fire at the U.S. Embassy in Moscow in August 1977. Most collections were made in the wild, although local botanical gardens and agricultural institutes sometimes shared seeds from their collections.

We usually had the services of a local botanist who provided many of the species identifications, some of which are yet in doubt. All seed was inspected by Soviet plant quarantine officers before shipment to Moscow. Upon entering the U.S., the seed was inspected by the Animal and Plant Health Inspection Service. Only one collection, Aleuropus repens, was refused admittance; the refusal was because it contained a rust not present in this country

\section{Collecting Areas}

Our itinerary called for 2 weeks in the northern foothills of the Caucasus Mountains (Stavropol), 1 week on the plains of northern Kazakhstan (Tselinograd), and 3 weeks in the mountains (Alma Ata) and desert regions (Dzhambul and Chimkent) of southern Kazakhstan (Fig. 1).

The city of Stavropol served as our headquarters while collecting in the northern Caucasus region, and we collected in an area radiating about $150 \mathrm{~km}$ from the city. This is a rich agricultural region at $45^{\circ} \mathrm{N}$ Latitude (comparable to Minneapolis-St. Paul) with elevations between 200 and 800 $\mathrm{m}$ and annual precipitation ranging from 20 to $75 \mathrm{~cm}$. The main Caucasus range is about $240 \mathrm{~km}$ to the south of Stavropol. The Stavropol Kray (Territory) is a climatic analog of Nebraska (C.I.A. 1974). The native vegetation consists, in part, of a rich and varied mixture of grasses (Bromus, Festuca, Agropyron, Phleum, and Bothriochloa) and legumes (Medicago, Astragalus, Trifolium, Lotus,

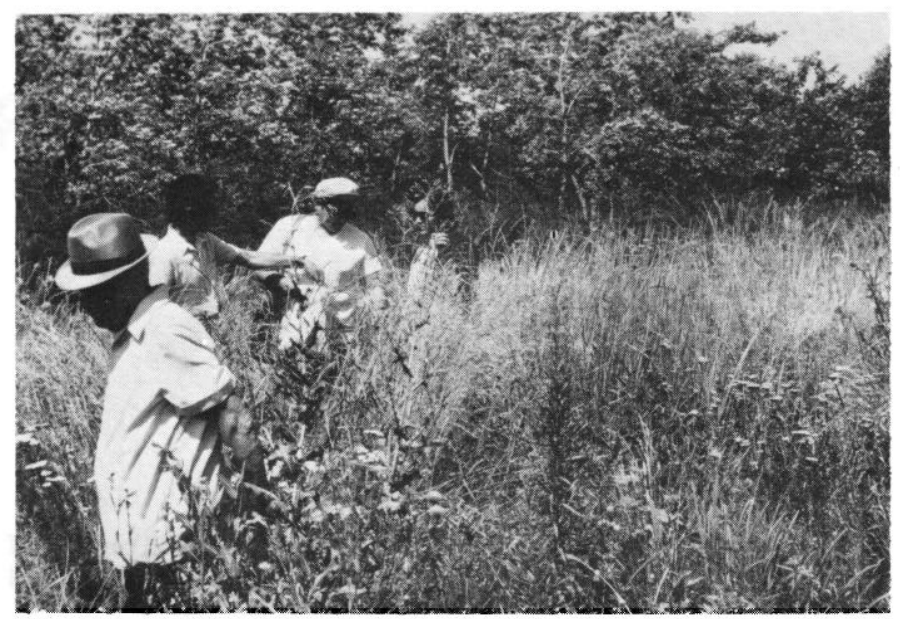

Fig. 3. Soviet botantists and plant collectors at rich collecting site on Mt. Strizhament near Stavropol.

Onobrychis, Vicia, and Lathyrus) (Fig. 3). Stavropol is in a transition zone where cool-season (Agropyron cristatum) and warm-season (Bothriochloa ischaemum) grasses are sometimes intermixed.

Tselinograd (formerly Akmolinsk) is in the heart of the "New Lands" area, where 60,000,000 ha have been broken out of native prairie and planted largely to wheat (Triticum aestivum). Tselinograd is close to $51^{\circ} \mathrm{N}$ Latitude (comparable to Calgary, Canada) at an elevation of about $300 \mathrm{~m}$. The Tselinograd Oblast (Region) is climatically and topographically similar to the Canadian prairies of Alberta and Saskatchewan (C.I.A., 1974). The native Tselinograd prairies are dominated by grasses (Fig. 4), principally Festuca sulcata and Stipa capillata. We were primarily interested in collecting Elymus junceus, E. angustus, Bromus inermis, Agropyron cristatum, and Medicago falcata, none of which were particularly abundant on the native prairie.

The three collecting areas of southern KazakhstanAlma Ata, Dzhambul, and Chimkent-are between 42 and $43^{\circ} \mathrm{N}$ Latitude (comparable to Salt Lake City, Utah) and the areas are climatically similar to much of the Intermountain Region (C.I.A. 1974). Alma Ata, the capital of Kazakh S.S.R., lies at the base of the Tien Shan Mountains, and most of our collecting was done in the nearby mountains at elevations up to $2,000 \mathrm{~m}$. The mountains around Alma Ata support a rich mixture of grasses, forbs, shrubs, and deciduous trees. Some of the more common grasses and legumes around Alma Ata

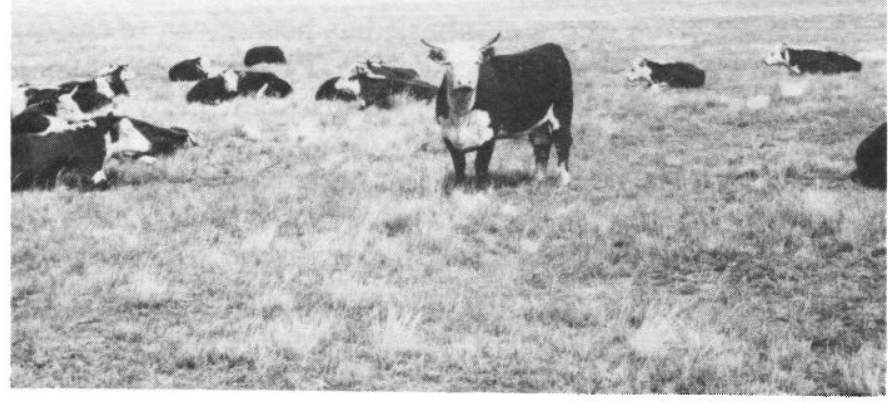

Fig. 4. Imported hereford cattle on native prairie near Tselinograd. 
include Agropyron, Brachypodium, Dactylis, Medicago, and Vicia species.

Dzhambul is on the fringe of a great sand desert, the Moyun-Kum, the elevation of which is around $600 \mathrm{~m}$. Annual precipitation is less than $20 \mathrm{~cm}$. Our most productive collecting was in the sand desert (Fig. 2) where the dominant vegetation consisted of shrubs (Artemisia and Calligonum), grasses (Agropyron), and legumes (Astragalus).

Chimkent is situated $200 \mathrm{~km}$ southwest of Dzhambul in an arid valley (about $600 \mathrm{~m}$ elevation) surrounded by low mountains to $1,600 \mathrm{~m}$. The area was heavily grazed by sheep, and collecting was possible only on nongrazed sites. Most collections were made in a mountainous game preserve where Agropyron, Dactylis, and Bromus species formed the major grass vegetation.

\section{The Collections}

The expedition obtained 1,094 seed collections representing about 251 species from 115 genera. However, not all collections were forage species because we also gathered seeds of trees, ornamentals, and miscellaneous plants whenever the opportunity arose. Main forage collections and their areas of origin are summarized in Table 1. Only those collections that appear to be particularly important or unique are discussed below.

\section{Grasses}

The largest collections were made of the crested wheatgrasses-Agropyron cristatum, $A$. desertorum, and $A$. sibiricum. The emphasis on crested wheatgrass reflects the senior author's interest in the plant-breeding potential and cytogenetic characteristics of this species-complex. The 16 collections of $A$. sibiricum from the Moyun-Kum Desert are particularly interesting because of their ability to thrive in almost pure sand. However, when grown under favorable conditions on heavy soils at Logan, those collections did rather poorly in the establishment year when compared with other crested wheatgrasses. The spikes of Moyun-Kum $A$. sibiricum are much narrower than other $A$. sibiricum accessions previously introduced into the U.S. A survey of the USDA Plant Inventories, which give the source of all introductions, indicates that crested wheatgrasses have not been previously introduced from the Moyun-Kum Desert.

The intermediate wheatgrasses (Agropyron intermedium and $A$. trichophorum) are widespread in the southern U.S.S.R. and we made many collections of those grasses (Table 1). The need to expand the germplasm base of intermediate wheatgrass is particularly critical because five of the seven bred varieties of intermediate wheatgrasses originate from one plant introduction, PI 98568 (Hanson 1972). This introduction came from the Maikop region, an area close to Stavropol. Hopefully, some of our collections from Stavropol will be as successful as PI $\mathbf{9 8 5 6 8 .}$

Some may question the need of bringing more quackgrass (Agropyron repens) and its close relative, $A$. elongatiforme (no common name), into the United States. However, these species are extremely diverse, and they may contain strains that are less aggressive than typical North American strains. Furthermore, interspecific hybrids with $A$. repens as one parent are some of our most productive grasses (Dewey 1976). The Soviets are breeding and promoting $A$. repens in the U.S.S.R. An $A$. repens breeding program has recently been initiated at the University of Wisconsin, River Falls (Louis J. Greub personal communication).

The 15 collections of Altai wildrye (Elymus angustus) should be of considerable interest to Canadian plant breeders and range scientists because they are conducting the only breeding program on E. angustus in North America at Swift Current, Saskatchewan (Lawrence 1970). Since our return, the Soviets have provided us with an additional 110 collections. This grass is a very coarse and robust species with stiff stems up to $2 \mathrm{~m}$ tall. It serves well as a winter pasture because the plants extend above the snow, and it is effective in catching and holding blowing snow. Our E. angustus collections should be well adapted to the Canadian prairies because they come from a climatically similar region in the Tselinograd Oblast.

Elymus ramosus (no common name) is considered to be a valuable forage grass in the U.S.S.R. (Nevski 1934). It is a low-growing, strongly rhizomatous species, and we encountered it on road cuts where it effectively bound the soil. It has been introduced previously as Agropyron ramosum (because it has single spikelets typical of Agropyron) but it has never gained importance either as a forage or a conservation species (Weintraub 1953). A major defect of E. ramosus is that it rarely produces seed. Its low seed set is probably duc to the absence of compatible pollen rather than to sterility per se. Inasmuch as it is almost certainly a self-sterile species, an E. ramosus plant requires foreign pollen to produce seed. Because the plants are so strongly rhizomatous, a single clone may cover a very large area and would not be exposed to pollen from other $E$. ramosus clones. This hypothesis can be tested very easily now that we have several sources of $E$. ramosus growing in close proximity.

Elymus multicaulis (no common name) has been introduced only once previously, in 1965 as PI 314665 and 314666. The additional nine collections from Dzhambul should provide a better estimate of the adaptation and forage value of $E$. multicaulis. This species is the Asian counterpart of North American beardless wildrye (E. triticoides) (Dewey 1972), although E. multicaulis is considerably more leafy and may be the better forage grass.

A major disappointment of the expedition was our failure to make appreciable collections of Russian wildrye (Elymus junceus). Our itinerary took us only to the fringes of the $E$. junceus distribution. At Shorthandy (near Tselinograd) we were able to make seven small collections. However, the Soviets supplied seed of an improved variety, 'Bozoisky,' which looks impressive at Logan. Since our return to the U.S., they have supplied an additional 25 collections of $E$. junceus.

According to our Soviet escort, a bromegrass specialist, the smooth bromegrass (Bromus inermis) from Tselinograd is tetraploid, $2 \mathrm{n}=28$. If so, it can be much more easily manipulated genetically than can typical $B$. inermis, which is octoploid, 2n=56 (Carnahan and Hill 1961).

The 12 collections of chee reedgrass (Calamogrostis epigeios) were made with little hope of obtaining seed, because all plants appeared to be totally sterile. Nevertheless, with careful threshing, some viable seeds were obtained from each collection. This grass is strongly rhizomatous and has considerable potential for soil stabilization purposes. The low seed set under natural conditions is probably due to the lack of compatible foreign pollen. Because of its strong spreading habit, an entire colony may be made up of a single 
Table 1. Forage collections obtained from the Soviet Union in 1977 by the Dewey-Plummer plant collecting expedition.

\begin{tabular}{|c|c|c|c|c|c|c|}
\hline \multirow[b]{2}{*}{ Species } & \multicolumn{5}{|c|}{ Collecting area } & \multirow[b]{2}{*}{ Total } \\
\hline & Stav. & Tselin. & Alma A. & Dzham. & Chim. & \\
\hline Achillea spp. & 10 & 2 & - & 1 & 2 & 15 \\
\hline Agropyron caninum & - & - & 4 & - & - & 4 \\
\hline cristatum & 40 & 9 & 6 & 1 & 11 & 67 \\
\hline desertorum & 73 & - & - & - & - & 73 \\
\hline elongatiforme & 16 & - & - & - & 1 & 17 \\
\hline intermedium 1 & 64 & - & - & 12 & 16 & 92 \\
\hline repens & 21 & 4 & 2 & 5 & - & 32 \\
\hline sibiricum & - & - & - & 16 & - & 16 \\
\hline Agrostis spp. & 3 & 1 & 2 & - & 2 & 8 \\
\hline Astragalus spp. & 8 & 6 & 2 & 7 & 2 & 25 \\
\hline Bothriochloa ischaemum & 7 & - & - & - & - & 7 \\
\hline Brachypodium spp. & 4 & - & 5 & - & - & 9 \\
\hline Bromus inermis & 13 & 10 & 4 & - & 5 & 32 \\
\hline riparius & 12 & - & - & - & 2 & 14 \\
\hline Calamagrostis epigeios & 6 & 4 & - & 2 & & 12 \\
\hline Calligonum spp. & - & - & - & 10 & - & 10 \\
\hline Carex spp. & 1 & 1 & 2 & 8 & 2 & 14 \\
\hline Coronilla varia & 7 & - & - & - & - & 7 \\
\hline Dactylis glomerata & 10 & - & 9 & - & 7 & 26 \\
\hline Elymus angustus & - & 15 & - & - & - & 15 \\
\hline junceus & - & 5 & 2 & - & - & 7 \\
\hline multicaulis & - & - & - & 9 & - & 9 \\
\hline ramosus & - & 5 & - & - & - & 5 \\
\hline Festuca arundinacea & 9 & 1 & - & 2 & 2 & 14 \\
\hline sulcata & 17 & 3 & 1 & 1 & 2 & 24 \\
\hline spp. & 6 & 1 & 3 & 6 & - & 16 \\
\hline Galium ruthenicum & - & 5 & & - & 6 & 11 \\
\hline Heracleum spp & 5 & - & & - & - & 5 \\
\hline Hordeum bogdanii & - & $\ldots$ & - & 2 & - & 2 \\
\hline bulbosum & - & - & - & - & 4 & 4 \\
\hline violaceum & 1 & 2 & - & - & - & 3 \\
\hline Iris spp. & 10 & 3 & - & 3 & 2 & 18 \\
\hline Koeleria spp. & 9 & - & - & - & 1 & 10 \\
\hline Lathyrus spp. & 7 & 1 & 2 & - & - & 10 \\
\hline Lotus spp. & 7 & 2 & - & 4 & - & 13 \\
\hline Medicago cancellata & 7 & - & - & - & - & 7 \\
\hline falcata & 1 & 7 & 4 & - & - & 12 \\
\hline romanica & 13 & 2 & - & & & 15 \\
\hline sativa & 2 & 3 & 3 & 11 & 9 & 28 \\
\hline Melilotus alba & 1 & 1 & - & 2 & - & 4 \\
\hline dentatus & I & - & - & - & - & 1 \\
\hline officinalis & 6 & 1 & 1 & 2 & 2 & 12 \\
\hline Onobrychis spp. & 8 & 4 & - & - & 1 & 13 \\
\hline Phalaris arundinacea & - & 2 & - & 1 & 2 & 5 \\
\hline Phleum phleoides & 8 & 2 & - & - & 1 & 11 \\
\hline Poa pratensis & 2 & 3 & 2 & 1 & 2 & 10 \\
\hline compressa & 4 & - & - & - & - & 4 \\
\hline Rosa spp. & 2 & 1 & 4 & 2 & 2 & 11 \\
\hline Salvia spp. & 3 & - & - & - & 2 & 5 \\
\hline Sanguisorba spp. & 1 & 2 & - & - & 1 & 4 \\
\hline Trifolium agrarium & 3 & - & - & - & - & 3 \\
\hline alpestre & 3 & - & - & - & - & 3 \\
\hline ambiguum & 48 & - & - & - & - & 48 \\
\hline diffusum & 3 & - & - & - & - & 3 \\
\hline fragiferum & 2 & - & - & 3 & - & 5 \\
\hline medium & 4 & - & & - & - & 4 \\
\hline pratense & 3 & - & 4 & - & 2 & 9 \\
\hline repens & 2 & - & - & - & 1 & 3 \\
\hline spp. & 7 & - & - & - & - & 7 \\
\hline Vicia angustifolia & 5 & - & - & - & - & 5 \\
\hline cracca & 3 & 4 & 5 & - & 1 & 13 \\
\hline tenuifolia & 5 & - & - & - & & 5 \\
\hline tetrasperma & 4 & - & - & - & - & 4 \\
\hline \multirow[t]{2}{*}{ spp. } & 4 & - & 2 & - & 1 & 7 \\
\hline & \multicolumn{3}{|c|}{ Grand Total } & & & 907 \\
\hline
\end{tabular}

IIncludes A. trichophorum 
clone. Presumably, seed set in our nurseries will be greatly improved because many different clones are growing in close proximity and can pollinate each other.

\section{Legumes}

Clovers (Trifolium spp) are especially abundant in the Stavropol Kray, and we acquired an extensive collection of kura clover (Trifolium ambiguum). Collections were made from accessions growing in the Stavropol Botanical Garden and in the wild. In addition, the botanical garden staff provided 18 seed lots that they had obtained over a wide range of elevations in the Caucasus Mountains. The 48 accessions that we obtained probably represent the largest single accumulation of $T$. ambiguum germplasm at one research location.

We found crown vetch (Coronilla varia) only in the Stavropol Kray. No unusual variations were noted at the time of collection. However, after the seedlings had been started in our greenhouse at Logan, Dr. M.D. Rumbaugh (USDASEA-AR, Logan, Utah) applied the vanillin- $\mathrm{HCl}$ tannin test to the leaves of each collection; two collections, both from the same area, contained some plants that were negative for the tannin test. As far as we know, these are the only tannin-free $C$. varia collections in the United States. Tannins reduce palatability and digestibility, and $C$. varia suffers as a forage crop because of those characteristics. A tannin-free crown vetch might have an advantage over existing varieties, and plant breeders should have particular interest in tannin-free accessions.

Biennial yellow and white sweet clover (Melilotus officinalis and $M$. alba) are widespread in the U.S.S.R., and we made a few collections in each area we visited. All collections were more or less typical. One collection of $M$. dentatus, which appeared to be $M$. officinalis, was pointed out to us by Dr. V.G. Tanfielev, a Soviet botanist. We were told that $M$. dentatus is much lower in coumarin than $M$. alba and $M$. officinalis. When grown at Logan, the M. dentatus accession was distinctive in that it was much less vigorous than the other sweetclovers. Furthermore, it was much less bitter to our taste, indicating that it is indeed low in coumarin. Low-coumarin lines of sweetclover can probably be developed by hybridizing $M$. dentatus with $M$. alba and $M$. officinalis.

Several alfalfa (Medicago) species were collected, and the purple-flowered (sativa) and yellow-flowered (falcata or romanica) types occurred in near-equal frequencies. The most distinctive alfalfa was $M$. cancellata, a yellow-flowered hexaploid with disc-like pods. This species grew in the Stavropol Kray on sandy sites in association with Agropyron desertorum. We made a special effect to locate "creeping" alfalfas throughout the expedition, but none was encountered.

More than 800 Astragalus species were described in Volume 12 of the Flora of the U.S.S.R. (Goncharov et al. 1946). Although we collected less than 20 Astragalus species, they represented a wide variety of plant types. Some have obvious potential as ornamentals; others appear to be good forage species, and some rhizomatous species may be useful as soil-binding plants. Many Astragalus species contain toxic compounds, particularly nitrates (Williams and Barneby 1977). Leaf samples of each Astragalus collection were analyzed for nitrate compounds by Dr. M.C. Williams (USDA-SEA-AR, Logan, Utah). Only one collection had a dangerous level of nitrate; one had a very low level of nitrate, and 24 had no nitrates (Williams 1978).

\section{Shrubs and Special-use Species}

The timing of the expedition (July-August) resulted in very few shrub collections because most range shrubs do not produce seed until later in the season. However, just recently the Soviets sent us cuttings of three sagebrush (Artemisia) species. Hopefully, other desert-shrub collections will be forthcoming.

Probably the most interesting shrub collections were those of Calligonum. This genus is composed of large desert shrubs with Ephedra-like leaves and it forms the dominant vegetation on extreme sandy sites in the Moyun-Kum Desert near Dzhambul. At most collecting sites, Calligonum grew in association with Agropyron sibiricum. The Soviets consider Calligonum species to be valuable for fuel and fixation of sand dunes. Although the plants that we saw showed little evidence of grazing, our escorts assured us that Calligonum is valuable as forage for sheep and camels.

Wild marjoram (Origanum vulgare) is a fine-stemmed, broad-leafed deciduous woody perennial that may be useful for soil conservation purposes. We collected this species on steep hillsides where it served as the main plant cover and was effective for binding the soil. The plants have decumbent stems, which produce adventitious roots at the lower nodes. This growth habit, coupled with prolific seed production, is conducive to the formation of dense stands. Because these hillsides were ungrazed, we had no means of determining its utilization by livestock, The leaves of $O$. vulgare are highly aromatic, and the shrub probably has limited acceptance by livestock.

Bedstraw (Galium ruthenicum), one of the few other woody perennials that we were able to obtain, was collected at widely separated sites in northern Kazakhstan (Tselinograd) and southern Kazakhstan (Chimkent). Nevertheless, all were similar in appearance, except that the southern collections were somewhat larger (stems to $50 \mathrm{~cm}$ ) than the northern collections (stems to $40 \mathrm{~cm}$ ). The bedstraws have limited value as forage plants, but they can form an appreciable part of the ground cover. The area around Tselinograd is typically saline, and our collections of Galium ruthenicum came from swales that appeared to be quite saline. These collections may have value for providing ground cover on saline-alkaline sites in the western United States.

The 15 yarrow ( $A$ chillea) collections were identified for us by the Soviets as $A$. millefolium, $A$. micrantha, or $A$. nobilis. The most notable variations were in foliage color (green and blue), flower color (white and yellow), and rhizome development (completely caespitose to strongly rhizomatous). None of the collections appeared to be particularly palatable to livestock. The rhizomatous collections are good soil binders and may be useful as conservation plants; other collections may find use as ornamentals.

Two cow parsnips, a giant-sized Heracleum mantegazzianum and $\boldsymbol{H}$. asperum, were lightly grazed by livestock. These species may find use on some of our mountain ranges.

Four collections of Thymus marschalianus, a perennial prostrate species that creeps by adventitious rooting at the nodes were made on sandy, severely grazed sites near Stavropol. This species formed a virtual turf on exposed knolls and should be good stabilizer on raw soils. The leaves are highly aromatic, and the plant may have potential as an ornamental, especially in rock gardens.

A sizeable collection of Iris, particularly I. pumila, was 
presented to us by the staff of the Stavropol Botanical Garden. Most of these collections came from the region between the Black Sea and Caspian Sea. In addition, we made a number of collections in the Asian interior near Tselinograd, Dzhambul, and Chimkent. For the most part, the Iris species were only lightly grazed and were of secondary importance as forage plants, but they may be useful for soil stabilization.

\section{Disposition of the Collections}

In the late fall of 1977, after the seed had been released by quarantine officials, the entire collection-forages, trees, ornamentals, etc.,- -was shipped to Logan, Utah, for threshing and cleaning. After threshing, about half of each seed lot was retained at Logan and the remainder was sent to the Regional Plant Introduction Station at Pullman, Washington. Some of the species will be grown and increased at Pullman and others will be increased at other Plant Introduction Stations. In the meantime, plant introduction (PI) numbers were assigned to each collection and they became officially incorporated into the National Plant Germplasm System.

The only location where the entire collection is being grown is Logan. All of the seed lots that could be germinated readily, about $90 \%$ of the total, were planted in the spring of 1978 in a 2-hectare planting on the Evans Farm of the Utah Agricultural Experiment Station. Ordinarily, 10 plants were established from each collection.

The collections will be evaluated for general adaptation at Logan. Great care is being exercised to prevent the escape or release of plants that have the potential of becoming weeds. With the aid of Dr. M.C. Williams, plants that contain toxic compounds will be identified.

Seed of those collections that appear to be useful for range and pasture purposes will be increased at Logan. Other collections will be increased at the various Plant Introduction Stations. As seed is increased in 1979 and later years, it will be made available to individuals and institutions for further research and evaluation. Range scientists and all others who might be interested in this collection are encouraged to observe the planting at Logan at any time beyond the spring of 1979 .

\section{Literature Cited}

Carnahan, H.L., and H.D. Hill 1961. Cytology and genetics of forage grasses. Bot. Rev. 27:1-162.

Central Intelligence Agency. 1974. U.S.S.R Agriculture Atlas. 59 p. U.S. Gov't Printing Office. Washington, D.C.

Dewey, D.R. 1972. Cytogenetics of tetraploid Elymus cinereus, E. triticoides, E. multicaulis. E. karataviensis, and their $\mathrm{F}_{1}$ hybrids. Bot. Gaz. 133:51-57.

Dewey, D.R. 1976. Derivation of a new forage grass from Agropyron repens $\times$ Agr spic. hybrids. Crop Sci. 16:175-180.

Dillman, A.C. 1946. The beginnings of crested wheatgrass in North America. Soc. Agron. 38:237-250.

Goncharov, N.F., A.G. Borisova, S.G. Gorshkova, M.G. Popov, and I.T. Vasilchenko. 1946. Leguminosae: Astragalus. In: V.L. Komarov (ed.) Flora of the U.S.S.R. Vol. XII. Israel Program for Scientific Translations. Jerusalem, Israel.

Hanson, A.A. 1972. Grass varieties in the United States. Agr. Handbk 170. U.S. Gov't Printing Office. Washington, D.C.

Harlan, J.R. 1976. The plants and animals that nourish man. Sci. Amer. 235:89-97.

Lawrence, T. 1970. Pasture attributes of Altai wild ryegrass. Can. J. Plant Sci. 50:743-745.

Nevski, S.A. 1934. Tribe Hordeae. p. 369-570. In: V.L. Komarov (ed.). Flora of the U.S.S.R. Vol. II. Israel Program for Scientific Translations. Jerusalem, Israel.

Plummer, A.P., D.R. Christensen, and S.B. Monsen. 1968. Restoring big game range in Utah. Utah State Div. Fish and Game Pub. 68-3. 183 p.

Weintraub, F.C. 1953. Grasses introduced into the United States. USDA Agr. Handbk 58.

Williams, M.C., and R.P. Barneby. 1977. The occurrence of nitro-toxins in North American Astragalus (Fabaceae). Brittonia 29:310-326.

Williams, M.C. 1978. Poisonous Plant Newsletter. Second Issue, p. 6-8.
ASSISTANT PROFESSOR with speciality in Range Management available in Division of Range Management at the University of Wyoming. Duties include teaching range principles and range planning, conducting research on grazing systems and range improvements, and participating in ongoing Extension programs. Ph.D. in range management is required. Training or experience in grazing management, range improvements, livestock management and/or range economics is desired. Closing date for applications is April 15, 1980. Position is available July 1,1980 . For further information on application procedure, contact: Dr. Michael A. Smith, Chairman of Search Committee, Division of Range Management, College of Agriculture, University of Wyoming, Laramie 82071. Phone: (307) 766-2337.
ASSISTANT OR ASSOCIATE PROFESSOR with speciality in Disturbed Land Reclamation available in Division of Range Management at the University of Wyoming. Duties include teaching, Extension, and research with an emphasis on reclamation of lands disturbed by mineral and energy development and other rangeland uses. Ph.D. in range management or closely related field with interest or experience in disturbed land reclamation is required. Training or experience in watershed management, plant physiology, and/or soils is desired. Closing date for applications is April 15, 1980. Position is available July 1, 1980. For further information on application procedure, contact: Dr. Quentin D. Skinner, Chairman of the Search Committee, Division of Range Management, College of Agriculture, University of Wyoming, Laramie 82071. Phone: (307) 766-4139. 